\title{
Effect of macroeconomic variables on systemic risk: Evidence from Vietnamese economy
}

\author{
Tram Thi Xuan Huong* • Nguyen Thi Thanh Hoai \\ University of Economics Ho Chi Minh City, Vietnam
}

Received: 31 December 2020

Revised:29 March 2021

Accepted: 30 March 2021

\begin{abstract}
This paper aims to identify the relationship between Vietnam's systemic risk and the effects of macroeconomic factors including exchange rate, interest rates, and economic growth. The data is collected from the Vietnamese stock market, specifically 29 listed financial firms (commercial banks, insurance firms, and securities companies) in 9 years from 2010 to 2018. The analysis is performed in two steps including measuring systematic risk in Vietnam based on the Systemic Expected Shortfall (SES) method and providing evidence from analysis related to the risk determinants assessment. We make use of four different estimators (OLS, REM, FEM, SGMM). The empirical evidence in this paper indicates that economic growth has a positive effect on systemic risk while the exchange rate has an inverse relationship with systemic risk in Vietnam, and the interest rate has a positive effect on systemic risk.
\end{abstract}

Keywords: macroeconomic variables; SES; systemic risk.

JEL Classification Codes: G20, E43, E52

\section{Introduction}

During the widespread financial crisis of 2007-2008, there were systemic risks that paralyzed the activities of the US region and quickly spread to European countries and the rest of the world. Since then, government policies and institutional decisions have changed based on the global financial system rather than on individual basis (Nkuutu et al., 2020). Acharya et al. (2017) and Brownlees \& Engle (2012) proposed the SES method to measure systemic risks and proved that it works well in forecasting the magnitude of the impact on major US banks during the 2007-2008 crisis. Gang \& Qian (2015), Zhou et al. (2020) have applied this method to the Chinese financial firms and the results showed that this method works in Chinese cases.

In Southeast Asia, Vietnam's economy and financial sector are evaluated as the one with a high level of risk. History bears out that, the impact of the financial crisis 2008 coupled with internal problems of Vietnam's economy made it unable to escape recession and inflation. The peak was that inflation in 2008 reached nearly $20 \%$ and maintained at two figures in 2010

\footnotetext{
*Corresponding author. E-mail: txhuong@ueh.edu.vn.
}

Citation: Huong, T. T. X., and Hoai, N. T. T. (2021) Effect of macroeconomic variables on systemic risk: Evidence from Vietnamese economy, Economics and Business Letters, 10(3), 217-228.

DOI: 10.17811/ebl.10.3.2021.217-228 
and 2011. Many international organizations have expressed concern that high inflation had deteriorated the business environment in Vietnam and had affected the value of Vietnam Dong. In order to maintain stability in the macroeconomic, identification in the systemic risk of the financial system, and of the factors that caused it is clearly essential. While the previous studies (Van \& Tran, 2019; Nguyen \& Vo, 2019) only concentrated on the systemic risk on the Vietnam stock market. This research contributes evaluation of the financial sector's systemic risk and assesses the impacts of macro variables on systemic risk. This research's obtained results might give policymakers opportunities to recognize the systemic risk effect, and to develop crucial steps for solving institutions' problems, and to create macroeconomic stability.

\section{Theoretical background}

\subsection{Systemic risk and its measurement}

\subsubsection{Definition of systemic risk}

It is possible to define the systemic risk as a possibility which can cause severe volatility or the collapse of an entire market or economy. However, that is not simply defined as such when the difference between the agents is selected for a system as well as the identification of the main factors that are responsible for system risks.

Some common definitions of systemic risk: Acharya (2009) defines systemic risk as the joint failure risk arising from the correlation of returns on the asset side of bank balance sheets. This definition is similar to which has been presented by Adrian \& Brunnermeier (2016). Federal Reserve Governor Daniel Tarullo ${ }^{1}$ defines it is "Financial institutions are systemically important if the failure of the firm to meet its obligations to creditors and customers would have significant adverse consequences for the financial system and the broader economy". The European Central Bank (ECB) (2010) defines it as a possibility of financial instability, so widespread that the functioning of the financial system is compromised to the point that economic development and welfare are significantly affected.

\subsubsection{Measuring systemic risk}

The critical consequences of the 2007-2009 Great Recession spurred studies of systemic risks from investors, researchers and government, as a preventive measure and limit future influences. These studies mainly focus on two main contents: the development of indicators on systemic risk forecasting (Kaminsky et al., 1998; Kaminsky \& Reinhart, 1999; Borio \& Drehemann, 2010; Alessi \& Detken, 2011; Behn et al., 2013; Hahm et al., 2013; Shin, 2013 ...) and the measurement of factors causing systemic risks as well as the contribution of financial institutions in each different markets.

Some methods particularly measure factors causing systemic risk as well as the contribution of financial institutions to systemic risk: CDSs (Rodriguez-Moreno \& Peña, 2013), VaR (Adrian \& Brunnermeier, 2016), SRISK ( Brownlees \& Engle, 2017), and SES (Acharya et al., 2017)...

In the above methods, the SES method has been widely supported and applied in many national studies (Gang \& Qian, 2015; Tarashev et al., 2016; Brownlees \& Engle, 2017; Zhou et al., 2020); SES method is appreciation in good agreement with the macroprudential supervision theory. The theoretical background for measuring the effect of individual systemic risk causing the decline in financial firms' stock prices during a crisis comes from Acharya \& Richardson (2009), Acharya et al. (2012) and Acharya et al. (2017). At the same time, this method can also determine the impact of each financial group in the whole system. SES also

\footnotetext{
1"Regulatory Restructuring," Testimony before the Committee on Banking, Housing, and Urban Affairs, U.S. Senate, Washington, D.C., July 23, 2009.
} 
increases the financial leverage and the expected margin of deficit (MES) of organizations when losses are concentrated in the two-tails of the loss distribution of the system. The research results show that the effect of financial institutions on financial system risk can be predicted by MES and leverage ratio. Then, policymakers and regulators can minimize the losses caused by systemic risks by timely adjusting appropriately macro indicators as well as controlling them and financial institutions that are at high risk of causing marginal risks and are occupying a significant proportion of leverage. Therefore, in this study, we will apply the SES method to measure systematic risks in Vietnam.

\subsection{Effect of macroeconomic factors on the systemic risk}

\subsubsection{Macroprudential regulation and macroeconomic variables}

Research results by Davis \& Karim (2010) have given evidence that financial crisis occurs from many causes and has many different specific stages. Therefore, the application of macro security monitoring can help the central bank promptly monitor the fluctuations of the financial market and timely forecast financial instability. Galati \& Moessner (2013) also emphasized the effectiveness of macro security tools in controlling market volatility and financial system risk.

Macro-level indicators act as predictors of market volatility, monitoring risks from unsustainable stresses as well as in the system as they tend to accumulate on balance loss by the whole. Some macroeconomic variables gathered from previous studies:

- Interbank interest rates: is a variable that represents overall on the daily credit market. The use of LIBOR gaps as a practical tool is commonly used in research and policy management (Brunnermeier, 2009). Some studies provided evidence of the positive effect of interest rates on systemic risk: Ramos-Tallada (2015), in case of stressful tightening monetary policy, interest rates have a positive impact on systemic risks; Laséen et al. (2017) showed that the tightening monetary policy did not reduce systemic risks, especially when the financial system is in a vulnerable period; Sabri et al. (2019) indicated that high short-term interest rates could increase the risk of a crisis. Therefore, we expect interest rates and systemic risk to have a positive relationship.

- Exchange rate: systemic risk can come from long-term foreign currency lending activities of banks (Yesin, 2013), as well as owning a large number of foreign exchange products on the derivatives (Mayordomo et al., 2014). Most of studies suggest that an increase in foreign exchange differences will increase systemic risk (Yesin, 2013; Mayordomo et al, 2014; Reboredo et al., 2016; De Mendonça \& da Silva, 2018), but there is also a view that foreign exchange differences and increasing systemic risk have a negative relationship because the devaluation of the local currency will positively affect the economy thus reducing the systemic risk (Hausmann et al., 2005), Di Nino et al., 2011).

- GDPG: Strong economic development, in the context of cycle theory, can be considered as a forecast of a potentially risky economic bubble for the whole system (Festic et al., 2011). On the contrary, when the economy is in recession, it can lead to tension in liquidity and the tendency of insolvency to increase in the banking system. Therefore, Alfaro \& Drehmann (2009) states signals for the variation of GDP overtime to warn a crisis outbreak. Many also mention the relationship between economic performances in general and GDP growth in particular with financial sustainability (Jarrow, 2014; Schleer \& Semmler, 2015).

Research hypothesis

Hypothesis 1: The relationship between interest rate and the systemic risk is positive.

Hypothesis 2: The relationship between variation of the exchange rate and the systemic risk is positive.

Hypothesis 3: The relationship between GDPG and systemic risk is negative. 


\section{Measuring systemic risk}

This study is going to use SES to measure systemic risk. Applying the results from Acharya et al. (2017)'s (see Appendix 1), using the daily returns, the financial firms of interest obtained, the each firm's market value of the equity, the book value of the properties, and the book value of the equity acquired for systemic risk calculation in the Vietnamese economy. In detail, we collected daily closing prices of shares and data of annual financial statements of financial institutions listed on the stock market in Vietnam in the period of 2010-2018 from Hanoi Stock Exchange (HNX) and Ho Chi Minh Stock Exchange (HOSE).

Appendix 3 presents the results of measuring systemic risk of the Vietnam financial institutions by the SES method from 2010 to 2018. In 2010, five highest ranked firms of SES are Viet Dragon Securities Corporation, VNDirect Securities Corporation, Asia - Pacific Investment Joint Stock Company, IB Securities Joint Stock Company, SSI Securities Corporation. All of them also have high rankings in MES (see Appendix 4). This observation highlights the importance of MES with systemic risk.

\section{Evaluate the effect of macroeconomic factors on the systemic risk}

\subsection{Data and methodologies}

Research data was collected from 29 public financial institutions in the 2010-2018 period. Interest rates were collected from The Asian Development Bank (ADB); exchange rate (US dollar/VND) and output growth were collected from the International Monetary Fund (IMF).

Based on the $\triangle \mathrm{CoVaR}$ framework, the systemic risk was assessed by De Mendonça and Da Silva (2018), where they had identified evidence from a panel data research conducted the systemic risk factors. This study uses the model from the study of De Mendonça \& Da Silva (2018), and then adjust to the form, as:

$$
S E S_{i}^{t}=\beta_{1} S E S_{i}^{t-1}+\beta_{2} L E V_{i}^{t}+\beta_{3} R O A_{i}^{t}+\beta_{4} \Delta E X_{i}^{t}+\beta_{5} I R_{i}^{t}+\beta_{6} G D P G_{i}^{t}+\varepsilon_{i}^{t}
$$

where:

- $L E V:$ degree of financial leverage $\left(L E V=\frac{\text { asset }}{\text { equtry }}\right)$;

- ROA: return on assets $\left(R O A=\frac{\text { net prof } i t}{\text { average total assets }}\right)$;

- $\triangle E X:$ variation of the exchange rate (US dollar/VND-average in the annual)

- IR: monetary policy interest rate

- GDPG: output growth in the annual

\subsection{Results and discussion}

Table 1 shows the projected panel data (OLS, REM, FEM and S-GMM). To test for the suitable models; we applied F-test for comparison of OLS vs FEM, Hausman-test for FEM vs REM. The result showed that the FEM model is more suitable compared to OLS and REM. Since the relationship between macroeconomic factors and systemic risk may be interoperable, we applied S-GMM regressions. In the Hansen test, S-GMM regressions acknowledge the validity of findings. In addition, the AR (2) serial autocorrelation test does not demonstrate the existence of serial correlation.

These results suggest that ROA is positive, but there isn't statistical significance in any model. The leverage's coefficient has a positive value, and in S-GMM models, there is statistical significance. This result agrees with the findings of other studies De Mendonça \& Da Silva (2018), Brunnermeier \& Pedersen (2009), Mayordomo et al. (2014), and Adrian \& Shin (2010).

The results show that macro variables are statistically significant to systemic risk, so the importance of monetary policy and state bank regulations to limit systemic risk in Vietnam is important. 
Table 1. Systemic risk estimation.

\begin{tabular}{lrrrr}
\hline \hline VARIABLES & OLS & FEM & REM & S-GMM \\
\hline SES $(-1)$ & $0.663^{* * *}$ & $0.190^{* *}$ & $0.663^{* * *}$ & $0.931^{* * *}$ \\
& -0.0573 & -0.0748 & -0.0573 & -0.0836 \\
LEV & 0.00314 & 0.0176 & 0.00314 & $0.0361^{* *}$ \\
& -0.00787 & -0.0304 & -0.00787 & -0.0138 \\
$R O A$ & 0.0638 & 0.0261 & 0.0638 & 0.462 \\
& -0.0897 & -0.085 & -0.0897 & -0.298 \\
$I R$ & $0.165^{* * *}$ & $0.116^{* * *}$ & $0.165^{* * *}$ & $0.188^{* * *}$ \\
& -0.0441 & -0.0399 & -0.0441 & -0.0494 \\
EXX & $-22.08^{* * *}$ & $-15.15^{* * *}$ & $-22.08^{* * *}$ & $-37.04^{* * *}$ \\
& -5.448 & -4.948 & -5.448 & -8.464 \\
GDPG & $0.388^{* * *}$ & $0.240^{* *}$ & $0.388^{* * *}$ & $0.268^{*}$ \\
& -0.107 & -0.101 & -0.107 & -0.154 \\
Constant & $-2.547^{* * *}$ & -0.603 & $-2.547 * * *$ & $-2.283^{*}$ \\
& -0.872 & -0.813 & -0.872 & -1.271 \\
\hline$R$-squared & 0.385 & & & 29 \\
$N$. Instruments & & & & $29 / 232$ \\
Stock Code & $29 / 232$ & $29 / 232$ & $29 / 232$ & 0.848 \\
IN.Obs. & & & & 0.210 \\
AR(2) & & & & 0.387 \\
Sargan test & & & & \\
Hansen test & & & & \\
\hline \hline
\end{tabular}

Note: Marginal significance levels: $(* * *),(* *),(*)$ indicates significant at $1 \%, 5 \%$ and $10 \%$. Source: own calculation

A negative correlation with $\triangle \mathrm{EX}$ is given by the systemic risk variable, and $\Delta \mathrm{EX}$ has statistical significance in all models. The result is contrary to the hypothesis, but similar results is obtained by Hausmann et al. (2005), Di Nino et al. (2011). Hence, it implies that the devaluation of currencies could reduce systemic risk in Vietnam, thus emphasizing the importance of financial supervision.

The variables belong to systemic risk indicate a positive correlation between IR and GDPG. For the IR variable, the positive and significant impact found on systemic risk is similar to the hypothesis and confirms previous theories of Ramos-Tallada (2015); De Mendonça \& da Silva (2018); Altavilla et al. (2018); Sabri et al. (2019).

For the GDPG variable, the positive impact of GDPG on systemic risk. This result is contrary to the hypothesis, it is difficult to explain this result, but according to Festic et al. (2011), strong economic development can be considered a forecast of a potentially risky economic bubble for the whole system.

\section{Conclusions}

This study measures the systemic risk in Vietnam from 2010 to 2018 using the SES method. It investigates the relationship between macroeconomic variables (interest rate, exchange rate, and output growth) and systemic risk in Vietnam. It suggests that higher exchange rates may decrease the systemic risk; economic growth may increase systemic risk, and low-interest rates can decrease systemic risk.

A further consequence is that the higher the level of financial leverage, the more vulnerable to economic volatility the firm is, which leads to an increase in systemic risk. In order to leverage their activities, financial companies depend on stable economic circumstances and therefore potentially ruin their balance sheets once the economic situation worsens. 
It will also be important for central banks to verify the potential effect of monetary policies on systemic risk. The research results suggest that, it seems a trade - off between economic growth and systemic risk in Vietnam and on the basis of monetary policy and economic growth, the equilibrium of the financial system in Vietnam can be sustained.

The future research can consider the effects of herding and financial derivatives on systematic risk in Vietnam (Huong Trang, 2018; Ju, 2019). It is a potential avenue, indeed.

\section{References}

Acharya, V. V. (2009). A theory of systemic risk and design of prudential bank regulation. Journal of financial stability, 5,(3): 224-255.

Acharya, V. V., Pedersen, L. H., Philippon, T., \& Richardson, M. (2017). Measuring systemic risk. The Review of Financial Studies, 30,(1): 2-47.

Adrian, T., \& Brunnermeier, M. K. (2016). CoVaR. The American Economic Review, 106,(7): $1705-1741$.

Alessi, L., \& Detken, C. (2011). Quasi real time early warning indicators for costly asset price boom/bust cycles: A role for global liquidity. European Journal of Political Economy, 27,(3): 520-533.

Alfaro, R., \& Drehmann, M. (2009). Macro stress tests and crises: what can we learn?

Altavilla, C., Boucinha, M., \& Peydró, J.-L. (2018). Monetary policy and bank profitability in a low interest rate environment. Economic Policy, 33,(96): 531-586.

Behn, M., Detken, C., Peltonen, T. A., \& Schudel, W. (2013). Setting countercyclical capital buffers based on early warning models: would it work?

Borio, C., \& Drehemann, M. (2010). Toward an operational framework for financial stability:'fuzzy'measurement and its consequences. Series on Central Banking, Analysis, and Economic Policies, no. 15.

Brownlees, C., \& Engle, R. F. (2017). SRISK: A conditional capital shortfall measure of systemic risk. The Review of Financial Studies, 30,(1): 48-79.

Brownlees, C. T., \& Engle, R. (2012). Volatility, correlation and tails for systemic risk measurement. Available at SSRN, 1611229.

Brunnermeier, M. K. (2009). Deciphering the liquidity and credit crunch 2007-2008. Journal of Economic perspectives, 23,(1): 77-100.

Davis, E. P., \& Karim, D. (2010). Macroprudential regulation-the missing policy pillar. National Institute Economic Review, 211,(1): 67-80.

De Mendonça, H. F., \& da Silva, R. B. (2018). Effect of banking and macroeconomic variables on systemic risk: An application of $\triangle \mathrm{COVAR}$ for an emerging economy. The North American Journal of Economics and Finance, 43: 141-157.

Di Nino, V., Eichengreen, B., \& Sbracia, M. (2011). Real Exchange Rates, Trade, and Growth: Italy 1861-2011, Bank of Italy, Economic Research and International Relations Area.

Di Nino, V., Eichengreen, B., \& Sbracia, M. (2011). Real Exchange Rates, Trade, and Growth: Italy 1861-2011. Bank of Italy Economic History Working Paper,(10).

Festić, M., Kavkler, A., \& Repina, S. (2011). The macroeconomic sources of systemic risk in the banking sectors of five new EU member states. Journal of Banking \& Finance, 35,(2): 310-322.

Galati, G., \& Moessner, R. (2013). Macroprudential policy-a literature review. Journal of Economic Surveys, 27,(5): 846-878.

Gang, J., \& Qian, Z. (2015). China's monetary policy and systemic risk. Emerging Markets Finance and Trade, 51,(4): 701-713. 
Hahm, J. H., Shin, H. S., \& Shin, K. (2013). Noncore bank liabilities and financial vulnerability. Journal of Money, Credit and Banking, 45,(s1): 3-36.

Hausmann, R., Pritchett, L., \& Rodrik, D. (2005). Growth accelerations. Journal of economic growth, 10,(4): 303-329.

Huong Trang, K. (2018), Financial derivatives use and multifaceted exposures: Evidence from East Asian non-financial firms, Journal of Asian Business and Economic Studies, 25(1), 86-108.

Jarrow, R. A. (2014). Financial crises and economic growth. The Quarterly Review of Economics and Finance, 54,(2): 194-207.

Ju, X.-K. (2019), Herding behaviour of Chinese A- and B-share markets, Journal of Asian Business and Economic Studies, 27(1), 49-65.

Kaminsky, G., Lizondo, S., \& Reinhart, C. M. (1998). Leading indicators of currency crises. Staff Papers, 45,(1): 1-48.

Kaminsky, G. L., \& Reinhart, C. M. (1999). The twin crises: the causes of banking and balance-of-payments problems. American Economic Review, 89,(3): 473-500.

Laséen, S., Pescatori, A., \& Turunen, J. (2017). Systemic risk: A new trade-off for monetary policy? Journal of financial stability, 32: 70-85.

Mayordomo, S., Rodriguez-Moreno, M., \& Peña, J. I. (2014). Derivatives holdings and systemic risk in the US banking sector. Journal of Banking \& Finance, 45: 84-104.

Nkuutu, G., Ntayi, J.M., Nkote, I.N., Munene, J. and Kaberuka, W. (2020), Board governance quality and risk disclosure compliance among financial institutions in Uganda, Journal of Asian Business and Economic Studies, 28(1), 64-81.

Nguyen, T. D.-T., \& Vo, D. H. (2019). The Determinants of Systematic Risk in Vietnam. Advances in Decision Sciences, 23,(2): 1-21.

Ramos-Tallada, J. (2015). Bank risks, monetary shocks and the credit channel in Brazil: Identification and evidence from panel data. Journal of international money and finance, 55: $135-161$.

Reboredo, J. C., Rivera-Castro, M. A., \& Ugolini, A. (2016). Downside and upside risk spillovers between exchange rates and stock prices. Journal of Banking \& Finance, 62: 7696.

Rodriguez-Moreno, M., \& Peña, J. I. (2013). Systemic risk measures: The simpler the better? Journal of Banking \& Finance, 37,(6): 1817-1831.

Sabri, A., Gilder, D., \& Onali, E. (2019). Monetary Policy and Systemic Risk. Available at SSRN 3499219.

Schleer, F., \& Semmler, W. (2015). Financial sector and output dynamics in the euro area: Non-linearities reconsidered. Journal of Macroeconomics, 46: 235-263.

Shin, M. H. S. (2013). Procyclicality and the search for early warning indicators, International Monetary Fund.

Tarashev, N., Tsatsaronis, K., \& Borio, C. (2016). Risk attribution using the Shapley value: Methodology and policy applications. Review of Finance, 20,(3): 1189-1213.

Van, V., \& Tran, D. (2019). Systemic Risk in Vietnam Stock Market. Asian Economic and Financial Review, 9: 339-352.

Yesin, P. (2013). Foreign currency loans and systemic risk in Europe, Working Paper, Study Center Gerzensee.

Zhou, H., Liu, W., \& Wang, L. (2020). Systemic Risk of China's Financial System (20072018): A Comparison between $\triangle \mathrm{CoVaR}$, MES and SRISK across Banks, Insurance and Securities Firms. The Chinese Economy, 53,(3): 221-245. 


\section{Appendix 1 - SES method}

Systemic Expected Shortfall (SES) is a model for assessing the contribution of each organization to systemic risk, in the form of a measure of the tendency to lack capital resulting in harm to the real economy in general and the system in particular. At the same time, according to the study of Acharya, Pedersen, Philippon, and Richardson (2017), SES is considered to be a solid foundation theory when studies direct its delegation by the following means:

- The stress test was conducted in spring (February) 2009 against banks' capital ratios consistently by the Supervisory Capital Assessment Program (SCAP), the results showed the SES of A company is determined based on the amount of capital required.

- Implemented systemic risk in equity is perceived based on a decline in equity valuation during a crisis, calculated through cumulative equity returns during the period from $7 / 2008$ to $12 / 2008$.

- Credit swaps of financial companies also pose a financial risk, as measured by CDS spreads accumulated during the same crisis period.

With the above evidence, studies aim to develop key indicators to forecast SES, in which marginal expected shortfall (MES) and leverage (LVG) is arguably the most important. The formula was published by Acharya, Pedersen, Philippon, and Richardson (2017):

$$
\frac{S E S^{i}}{w_{0}^{i}}=\frac{z a^{i}}{w_{0}^{i}}-1-E\left[\frac{w_{1}^{i}}{w_{0}^{i}}-1 \mid W_{i}<z A\right]
$$

in which: SESi : systemic expected shortfall; $a i$ : total asset; $w_{0}^{i}$ : equity capital; $w_{1}^{i}$ : The net worth of the bank, at time $1 ; A$ : the aggregate assets in the system; $W_{i}$ : the aggregate banking capital; $z$ : a crisis happens when the aggregate capital $W_{\mathrm{i}}$ is below $\mathrm{z}$ times aggregate assets $\mathrm{A}$.

Measuring the marginal potential MES loss at a typical risk level of alpha $=5 \%$ using frequent market returns results. This implies that in any given year, taking the \% lowest days for the average returns $(\mathrm{R})$ and then measuring the equal-weighted average return on any given company $\left(\mathrm{R}^{\mathrm{b}}\right)$ for these days:

$$
M E S_{5 \%}^{b}=\frac{1}{\# \text { days }} \sum R_{t}^{b}
$$

(t: system is in its $5 \%$ tail)

Because of limited and infrequent market data, especially on the breakdown of off-and onbalance sheet financing, Acharya, Pedersen, Philippon and Richardson (2017) apply the standard leverage approximation, denoted LVG, because it is not a straightforward process to calculate true leverage.

$$
\begin{aligned}
& L V G^{b}=\frac{\text { quasi }- \text { market value of assets }}{\text { market value of equity }} \\
& =\frac{\text { book assets }- \text { book equity }+ \text { market equity }}{\text { market value of equity }}
\end{aligned}
$$

We need to choose the parameter $z$ and choose the risk level of the MES corresponding to a systemic crisis to estimate SES.

Regarding to this, we set $z=6 \%$ based on Tier-1 Basel capital requirements, and we project the crisis-level market lost to be a $60 \%$ drop in financial firms' equity. Specifically, we calculate SES as follows:

$$
S E S_{t}^{i}=\frac{60}{1.4} M E S_{5 \%}+0.06 L V G_{t}^{i}-1
$$




\section{Appendix 2 - Detail of the Vietnam financial institutions applied in the research}

\begin{tabular}{|c|c|c|c|c|}
\hline $\begin{array}{l}\text { Stock } \\
\text { Code }\end{array}$ & Tame & $\begin{array}{l}\text { Stock } \\
\text { Exchange }\end{array}$ & $\begin{array}{l}\text { Total assets } \\
\text { in } 2010 \\
\text { (Billion } \\
\text { VND) } \\
\end{array}$ & $\begin{array}{l}\text { Total assets } \\
\text { in } 2018 \\
\text { (Billion } \\
\text { VND) }\end{array}$ \\
\hline ACB & sia Commercial Bank & HNX & $205,801.58$ & $329,333.24$ \\
\hline AGR & gribank Securities Corporation & IOSE & $4,175.90$ & $1,917.07$ \\
\hline APG & APG Securities Joint Stock Company & HOSE & 140.91 & 148.87 \\
\hline API & $\begin{array}{l}\text { Asia - Pacific Investment Joint Stock } \\
\text { Company }\end{array}$ & HNX & 313.36 & $1,777.87$ \\
\hline APS & $\begin{array}{l}\text { Asia - Pacific Securities Joint Stock } \\
\text { Company }\end{array}$ & HNX & $1,248.17$ & 396.37 \\
\hline BMI & Bao Minh Insurance Corporation & HOSE & $3,818.54$ & $5,544.71$ \\
\hline $\mathrm{BVH}$ & Bao Viet Holdings & HOSE & $44,767.94$ & $113,768.69$ \\
\hline BVS & Baoviet Securities Company & HNX & $1,612.16$ & $2,927.03$ \\
\hline CTG & $\begin{array}{l}\text { Vietnam Joint Stock Commercial Bank } \\
\text { for Industry and Trade }\end{array}$ & HOSE & $367,931.81$ & $1,164,318.27$ \\
\hline CTS & $\begin{array}{l}\text { Viet Nam Bank For Industry \& Trade } \\
\text { Securities JSC }\end{array}$ & HOSE & $1,034.71$ & $2,576.52$ \\
\hline EIB & $\begin{array}{l}\text { Vietnam Commercial Joint Stock Export } \\
\text { Import Bank }\end{array}$ & HOSE & $131,127.96$ & $152,708.81$ \\
\hline HAC & $\begin{array}{l}\text { Hai Phong Securities Joint Stock } \\
\text { Company }\end{array}$ & UPCoM & 374.02 & 303.61 \\
\hline $\mathrm{HCM}$ & Ho Chi Minh City Securities Corporation & HOSE & $2,524.98$ & $5,256.31$ \\
\hline OGC & Ocean Group Joint Stock Company & HOSE & $7,430.57$ & $4,715.56$ \\
\hline PSI & Petrovietnam Securities Incorporated & HNX & .52 & 647.67 \\
\hline PVI & PVI Holdings & HNX & $6,453.10$ & $19,824.19$ \\
\hline PVR & Hanoi PVR Investment JSC & UPCoM & $1,024.23$ & $1,026.91$ \\
\hline SBS & $\begin{array}{l}\text { Sacombank Securities Joint Stock } \\
\text { Company }\end{array}$ & UPCoM & $9,178.32$ & 444.02 \\
\hline SHB & $\begin{array}{l}\text { Saigon Hanoi Commercial Joint Stock } \\
\text { Bank }\end{array}$ & HNX & 51 , & $323,338.62$ \\
\hline SHS & Saigon - Hanoi Securities JSC & HNX & & $4,869.33$ \\
\hline SSI & SSI Securities Corporation & HOSE & $8,792.89$ & $23,825.63$ \\
\hline STB & $\begin{array}{l}\text { Sai Gon Thuong Tin Commercial Joint } \\
\text { Stock Bank }\end{array}$ & HOSE & 50.90 & $406,040.60$ \\
\hline VCB & Bank for Foreign Trade of Vietnam & HOSE & $307,614.51$ & $1,072,983.28$ \\
\hline VDS & Viet Dragon Securities Corporation & HOSE & $1,082.00$ & $1,932.34$ \\
\hline VIG & $\begin{array}{l}\text { Viet Nam Industrial \& Commercial } \\
\text { Securities Corporation }\end{array}$ & HNX & 584.40 & 232.50 \\
\hline VIX & IB Securities Joint Stock Company & HNX & 435.92 & $1,530.28$ \\
\hline VND & VNDirect Securities Corporation & HOSE & $3,119.83$ & $10,544.09$ \\
\hline VNR & Vietnam National & & & \\
\hline VINT & Cor & HNX & $3,667.76$ & $6,673.93$ \\
\hline WSS & Wall Street Securities Company & HNX & 526.23 & 649.46 \\
\hline
\end{tabular}

Source: Hanoi Stock Exchange (HNX) and Ho Chi Minh Stock Exchange (HOSE). 


\section{Appendix 3 - Systemic risk of the Vietnam financial institutions}

Colume Stock Code shows the stock symbol of Vietnam financial institutions applied in the research.

\begin{tabular}{|c|c|c|c|c|c|c|c|c|c|}
\hline \multicolumn{10}{|l|}{ Stock } \\
\hline Code & 2010 & 2011 & 2012 & 2013 & 2014 & 2015 & 2016 & 2017 & 2018 \\
\hline ACB & 1.52 & 1.20 & 2.44 & 0.68 & 0.78 & 1.36 & 1.10 & 0.71 & 2.60 \\
\hline AGR & 1.86 & 1.42 & 1.28 & 1.41 & 1.81 & 1.30 & 1.30 & 1.72 & 1.66 \\
\hline APG & 2.30 & 2.25 & 2.08 & 2.82 & 2.81 & 2.99 & 2.51 & 2.03 & 1.67 \\
\hline API & 2.79 & 2.19 & 2.12 & 2.29 & 2.87 & 1.99 & 1.97 & 2.35 & 3.15 \\
\hline APS & 2.42 & 2.06 & 2.16 & 1.83 & 2.71 & 1.41 & 1.78 & 1.75 & 1.58 \\
\hline BMI & 1.20 & 1.53 & 1.55 & 1.61 & 1.70 & 1.39 & 0.85 & 0.33 & 1.48 \\
\hline $\mathrm{BVH}$ & 1.20 & 1.24 & 1.24 & 1.64 & 1.42 & 1.57 & 0.89 & 0.43 & 1.75 \\
\hline BVS & 1.74 & 1.79 & 1.93 & 1.28 & 2.23 & 0.68 & 0.57 & 0.12 & 0.93 \\
\hline CTG & 1.63 & 1.98 & 2.10 & 1.47 & 0.88 & 1.52 & 1.19 & 1.21 & 2.85 \\
\hline CTS & 1.55 & 1.62 & 1.88 & 0.92 & 2.19 & 0.71 & 0.68 & 1.26 & 1.64 \\
\hline EIB & 1.37 & 1.11 & 1.61 & 0.76 & 1.09 & 1.26 & 1.67 & 1.50 & 1.46 \\
\hline HAC & 2.47 & 2.11 & 2.04 & 1.98 & 1.56 & 2.45 & 2.81 & 1.87 & 2.20 \\
\hline HCM & 1.18 & 1.55 & 1.11 & 1.50 & 1.88 & 0.94 & 0.76 & 1.01 & 1.94 \\
\hline OGC & 1.20 & 1.59 & 1.33 & 1.78 & 2.02 & 1.93 & 2.51 & 2.44 & 2.10 \\
\hline PSI & 1.58 & 2.02 & 2.41 & 1.95 & 2.24 & 2.88 & 3.15 & 2.92 & 2.25 \\
\hline PVI & 1.74 & 1.42 & 1.24 & 0.95 & 1.65 & 1.75 & 0.71 & 0.91 & 1.04 \\
\hline PVR & 1.83 & 2.29 & 1.99 & 3.52 & 2.98 & 2.33 & 3.07 & 3.73 & 5.28 \\
\hline SBS & 1.26 & 1.58 & 2.99 & 2.42 & 1.94 & 2.79 & 3.46 & 3.50 & 3.42 \\
\hline SHB & 2.19 & 2.70 & 3.13 & 2.49 & 2.93 & 2.69 & 3.82 & 2.43 & 3.75 \\
\hline SHS & 2.35 & 2.22 & 2.15 & 1.90 & 2.78 & 1.70 & 1.31 & 1.51 & 2.27 \\
\hline SSI & 2.49 & 1.11 & 1.18 & 0.54 & 1.41 & 1.02 & 0.40 & 0.55 & 1.86 \\
\hline STB & 1.54 & 1.18 & 1.47 & 1.46 & 1.22 & 1.96 & 2.08 & 2.30 & 2.57 \\
\hline VCB & 1.48 & 1.54 & 1.48 & 1.48 & 1.66 & 1.36 & 1.60 & 0.29 & 1.84 \\
\hline VDS & 2.96 & 2.48 & 2.61 & 2.94 & 2.72 & 2.17 & 1.38 & 1.78 & 1.64 \\
\hline VIG & 2.18 & 1.94 & 2.07 & 2.85 & 2.94 & 1.21 & 2.35 & 2.37 & 2.30 \\
\hline VIX & 2.69 & 2.73 & 1.97 & 2.72 & 2.97 & 2.83 & 1.62 & 1.60 & 2.39 \\
\hline VND & 2.79 & 1.91 & 1.97 & 0.99 & 2.07 & 1.13 & 0.87 & 1.13 & 2.61 \\
\hline VNR & 1.29 & 3.63 & 1.78 & 2.86 & 2.87 & 2.60 & 0.83 & 1.67 & 1.52 \\
\hline WSS & 2.19 & 1.79 & 1.93 & 1.64 & 2.38 & 1.26 & 2.00 & 1.49 & 1.55 \\
\hline
\end{tabular}

Source: Own calculation. 


\section{Appendix 4 - Systemic risk ranking and MES ranking of financial firms in 2010}

The descriptive statistics of the study are provided in table 2. Most descriptive statistical results show relatively high variation in variables, that is, changes in economic cycles in the research period.

\begin{tabular}{|c|c|c|c|c|c|}
\hline Stock Code & MES & LVB & SES & $\begin{array}{r}\text { SES } \\
\text { Ranking }\end{array}$ & $\begin{array}{r}\text { MES } \\
\text { Ranking }\end{array}$ \\
\hline$\overline{\mathrm{ACB}}$ & $4.41 \%$ & 10.57 & 1.52 & 21 & 28 \\
\hline AGR & $5.94 \%$ & 5.19 & 1.86 & 13 & 15 \\
\hline APG & $7.55 \%$ & 1.03 & 2.30 & 9 & 9 \\
\hline API & $8.68 \%$ & 1.12 & 2.79 & 3 & 2 \\
\hline APS & $7.59 \%$ & 2.77 & 2.42 & 7 & 7 \\
\hline BMI & $4.82 \%$ & 2.34 & 1.20 & 26 & 24 \\
\hline BVH & $4.87 \%$ & 1.84 & 1.20 & 28 & 22 \\
\hline BVS & $6.22 \%$ & 1.23 & 1.74 & 16 & 13 \\
\hline CTG & $4.58 \%$ & 11.04 & 1.63 & 17 & 26 \\
\hline CTS & $5.79 \%$ & 1.24 & 1.55 & 19 & 16 \\
\hline EIB & $4.41 \%$ & 8.11 & 1.37 & 23 & 29 \\
\hline HAC & $7.95 \%$ & 1.05 & 2.47 & 6 & 6 \\
\hline $\mathrm{HCM}$ & $4.88 \%$ & 1.52 & 1.18 & 29 & 21 \\
\hline OGC & $4.91 \%$ & 1.66 & 1.20 & 27 & 20 \\
\hline PSI & $5.64 \%$ & 2.64 & 1.58 & 18 & 18 \\
\hline PVI & $6.12 \%$ & 1.99 & 1.74 & 15 & 14 \\
\hline PVR & $6.29 \%$ & 2.22 & 1.83 & 14 & 12 \\
\hline SBS & $4.86 \%$ & 2.92 & 1.26 & 25 & 23 \\
\hline SHB & $5.76 \%$ & 12.02 & 2.19 & 11 & 17 \\
\hline SHS & $7.59 \%$ & 1.62 & 2.35 & 8 & 8 \\
\hline SSI & $7.96 \%$ & 1.30 & 2.49 & 5 & 5 \\
\hline STB & $4.49 \%$ & 10.32 & 1.54 & 20 & 27 \\
\hline $\mathrm{VCB}$ & $4.73 \%$ & 7.66 & 1.48 & 22 & 25 \\
\hline VDS & $8.82 \%$ & 2.96 & 2.96 & 1 & 1 \\
\hline VIG & $7.19 \%$ & 1.66 & 2.18 & 12 & 11 \\
\hline VIX & $8.43 \%$ & 1.30 & 2.69 & 4 & 4 \\
\hline VND & $8.60 \%$ & 1.78 & 2.79 & 2 & 3 \\
\hline VNR & $5.07 \%$ & 1.87 & 1.29 & 24 & 19 \\
\hline WSS & $7.24 \%$ & 1.51 & 2.19 & 10 & 10 \\
\hline
\end{tabular}

Source: own calculation 


\section{Appendix 5 - Descriptive statistics of the variables}

Appendix 5 displays the correlation matrix to assess the relationships between the variables calculated in the study and the systemic risk. The correlation coefficients between the independent variables are smaller than 0.8 , so the possibility of the collinearity phenomenon in the model is quite low.

\begin{tabular}{lrrrrrr}
\hline \hline Variable & SES & LEV & ROA & IR & $\Delta$ EX & GDPG \\
\hline Mean & 1.8715 & 4.4942 & 0.0433 & 8.0000 & 0.0293 & 6.2327 \\
Std. Dev. & 0.7478 & 5.2032 & 0.4314 & 2.6900 & 0.0268 & 0.5759 \\
Min & 0.1206 & -4.6901 & -0.2807 & 6.2500 & 0.0075 & 5.2470 \\
Max & 5.2844 & 21.0720 & 5.1300 & 15.0000 & 0.0801 & 7.0760 \\
Obs & 261 & 261 & 261 & 261 & 261 & 261 \\
\hline \hline
\end{tabular}

Source: Own calculation.

\section{Appendix 6 - Correlation matrix}

Moreover, the results of the VIF (variance inflation factor) show evidence of all coefficients less than 10. Values of VIF smaller than 10 are often regarded as indicating no multicollinearity.

\begin{tabular}{lllllll}
\hline \hline & $\boldsymbol{S E S}$ & $\boldsymbol{L E V}$ & $\boldsymbol{R O A}$ & $\boldsymbol{I R}$ & $\boldsymbol{A E X}$ & $\boldsymbol{G D P G}$ \\
\hline $\boldsymbol{S E} \boldsymbol{S}$ & 1.000 & & & & & \\
$\boldsymbol{L E V}$ & -0.072 & 1.000 & & & & \\
$\boldsymbol{R} \boldsymbol{O A}$ & -0.045 & -0.059 & 1.000 & & & \\
$\boldsymbol{I R}$ & 0.004 & -0.029 & -0.077 & 1.000 & & \\
$\boldsymbol{A} \boldsymbol{E} \boldsymbol{X}$ & -0.020 & 0.009 & -0.031 & 0.762 & 1.000 & \\
$\boldsymbol{G D P G}$ & 0.009 & 0.084 & 0.026 & -0.194 & 0.230 & 1.000 \\
\hline \hline
\end{tabular}

Source: Own calculation.

\section{Appendix 7 - The Variance Inflation factors (VIF) test result}

\begin{tabular}{lcc}
\hline \hline Variable & VIF & I/VIF \\
\hline$\Delta$ EX & 9.59 & 0.10427 \\
IR & 9.63 & 0.103851 \\
GDPG & 2.62 & 0.382362 \\
SES(-1) & 1.06 & 0.946779 \\
LEV & 1.03 & 0.97142 \\
ROA & 1.04 & 0.960583 \\
\hline Mean VIF & 4.16 & \\
\hline \hline
\end{tabular}

Source: Own calculation. 